\title{
Comparison of measured and modeled UV spectral irradiance at the Izaña station based on LibRadtran and UVA-GOA models
}

\section{Comparación entre la irradiancia espectral UV medida experimentalmente en la estación de Izaña y simulada con los modelos de transferencia radiativa LibRadtran y UVA-GOA}

\author{
R. D. García(1,2,*), V. E. Cachorro(2,S), E. Cuevas(1), A. Redondas(1), \\ A. M. de Frutos $(2, S)$, A. Berjón( $2,3, S)$ \\ 1. Izaña Atmospheric Research Center, Meteorological State Agency of Spain, AEMET, Spain. \\ 2. Atmospheric Optics Group. Valladolid University (GOA-UVA), Spain. \\ 3. Laboratoire d'Optique Atmosphérique (LOA), Université Lille, France. \\ (") Email: rgarciac@aemet.es S: miembro de SEDOPTICA / SEDOPTICA member \\ Recibido / Received: 30/01/2011. Aceptado / Accepted: 30/08/2011.
}

\begin{abstract}
:
In this work we have compared UV spectral global irradiance measurements performed with the spectroradiometer Bentham DMT 300 (UIIMP, University of Innsbruck, Institute of Medical Physics Austria, ATI) and the simulations obtained with two radiative transfer models: UVA-GOA and LibRadtran. The measurements were performed on $1^{\text {st }}$ June 2005, during the QASUME (Quality Assurance of Solar Ultraviolet Spectral Irradiance Measurements) intercomparison campaign at the Izaña (Tenerife) observatory. The results of UVA-GOA model shows differences with experimental data between $50 \%$ and $70 \%$ for wavelengths lower than $320 \mathrm{~nm}$, which decrease to $10 \%$ around 320 $\mathrm{nm}$. For the LibRadtran model the differences range from $20 \%$ at $280 \mathrm{~nm}$ to $3 \%-5 \%$ at $320 \mathrm{~nm}$. These differences, which are in the range of ozone absorption, are due to the simplified approach used in UVA-GOA to treat the absorption-transmittance. For the range between $320 \mathrm{~nm}$ and $400 \mathrm{~nm}$, the differences are lower than $6 \%$ (i.e. within the experimental error) for the comparison between both models and the measurements.
\end{abstract}

Keywords: Izaña, LibRadtran Model, UVA-GOA Model, Solar UV Irradiance.

\section{RESUMEN:}

En este trabajo comparamos las medidas espectrales de irradiancia UV global tomadas experimentalmente con un espectrorradiómetro Bentham DMT-300 (Universidad de Innsbruck, Instituto de Física Médica, Austria, ATI) y las simuladas con los modelos de transferencia radiativa LibRadtran y UVA-GOA. Las medidas comparadas fueron tomadas el 1 de Junio de 2005, coincidiendo con la campaña de intercomparación QASUME (Quality Assurance of Solar Ultraviolet Spectral Irradiance Measurements) que tuvo lugar en el Observatorio de Izaña (Tenerife). Los resultados muestran que para longitudes de onda menores a $320 \mathrm{~nm}$ el modelo UVA-GOA difiere entre un $50 \%$ y un $70 \%$ con las medidas experimentales pero éstas decrecen hasta un $10 \%$ entorno a $320 \mathrm{~nm}$. En cambio, con el modelo LibRadtran obtenemos unas diferencias del $20 \%$ a $280 \mathrm{~nm}$ y entre el $3 \%$ y el $5 \%$ a $320 \mathrm{~nm}$. Estas diferencias entre ambos modelos se deben a la forma simplificada en que el modelo UVA-GOA trata el proceso de absorción selectiva de gases y por tanto su función de transmitancia. Sin embargo, para el rango comprendido entre $320 \mathrm{~nm}$ y $400 \mathrm{~nm}$, las diferencias entre ambos modelos y con las medidas experimentales son inferiores al 6\%, del orden del error de las medidas experimentales.

Palabras clave: Izaña, Modelo LibRadtran, Modelo UVA-GOA, Irradiancia Solar UV. 


\section{REFERENCIAS Y ENLACES / REFERENCES AND LINKS}

[1]. http://www.aemet.izana.org

[2]. A. Bais , M. Blumthaler, A. Webb, G. Seckmeyer, S. Thiel, S. Kazadzis, A. Redondas, R. Kift, N. Kouremeti, B. Schallhart, R. Schmitt, D. Pisulla, J. P. Díaz, O. García, A. M. Díaz Rodríguez, A. Smedley, , Proc. SPIE 5886, 1-10 (2005).

[3] LibRadtran User's Guide at http://www.libradtran.org .

[4]. B. Mayer, A. Killing. "Technical note: The LibRadtran software package for radiative transfer calculations - description and examples of use", Atmos. Chem. Phys. 5, 1855-1877 (2005).

[5]. K. Stamnes, S. Tsay, W. Wiscombe, K. Jayaweera, "A numerically stable algorithm for discreteordinate-method radiativa transfer in multiple scattering and emitting layered media", Appl. Opt. 27, 2502-2509 (1988).

[6]. E. Cuevas, Estudio del Comportamiento del Ozono Troposférico en la Estación de Izaña (Tenerife) y la Relación con la Dinámica Atmosférica, PhD Thesis, Universidad Complutense de Madrid, Spain (1995).

[7]. AERONET (Aerosol Robotic Network): http://aeronet.gsfc.nasa.gov .

[8]. P. Durán, Medidas Espectroradiométricas para la Determinación de Componentes Atmosféricos Ozono, Vapor de Agua y Aerosoles y Modelización del Intercambio Radiativo en la Atmósfera, Ph. D. Thesis, University of Valladolid, Spain (1997).

[9]. V. E. Cachorro, R. Vergaz, A. M.de Frutos, “Características del modelo de radiación en el rango visiblecercano infrarrojo y ultravioleta UVA_GOA", Technical Report, GOA-UVA at INM (2000).

[10].V. V. Sobolev, “A treatise on radiative transfer”, D. Van Nostrand Company, Inc (1963).

[11]. E. Vermote, D. Tanre, J. L. Deuze, M. Herman, J. J. Morcrette, "Second simulation of the satellite signal in the solar spectrum (6S)", Laboratoire d'Optique Atmosphérique LOA, Université de Lille, France (1985).

[12].V. E. Cachorro, R. Vergaz, M. Sorribas, A. M. De Frutos, "Descripción y estudio de sensibilidad del modelo de radiación ultravioleta "UVA-GOA", Proceedings 3a Asamblea Hispano-Portuguesa de Geodesia y Geofísica, Tomo II, pp. 1219-23 (S13), .ISBN: 84-9705-299-4, Valencia, Spain (2002).

[13].V. E. Cachorro, R. Vergaz, J. M. Vilaplana, A. M. De Frutos, B. De la Morena, “Comparación precisa entre la irradiancia global espectral en el UV dada por el espectrorradiómetro Brewer \#150 y el modelo UVA-GOA en la estación de "El Arenosillo" (INTA)", Proceedings 3a Asamblea Hispano-Portuguesa de Geodesia y Geofísica, Tomo II, pp. 1224-28 (S13), ISBN: 84-9705-299-4, Valencia, Spain (2002).

[14]. R. D. García, Análisis de la Capacidad de los Modelos de Transferencia Radiativa para la Calibración de los Radiómetros: Aplicación al Radiómetro NILU-UV, Diploma de Estudios Avanzados (DEA), Universidad de Valladolid, Spain. Nota Técnica Digital № 4 del Centro de Investigación Atmosférico de Izaña (NTD CIAI-4), Agencia Estatal de Meteorología, Ministerio de Medio Ambiente y Medio Marino y Rural. NIPO 784-09-012-2 (2008).

\section{Introduction}

The UV solar radiation reaching the Earth's surface is composed of the UV-B radiation with a wavelength range of $280-320 \mathrm{~nm}$ and the UV-A radiation from this limit to $400 \mathrm{~nm}$. The measurements in both ranges are performed by radiometric or spectroradiometric systems which are of great interest because of the importance of this radiation for the life on Earth. Because of the relative difficulty of the latter measurements, radiative transfer models (RTM) are also powerful tools for the evaluation of this solar irradiance, and for testing the quality of the experimental data through the comparison process.
The objective of this paper is to compare UV spectral global irradiance measurements with those simulated with LibRadtran and UVA-GOA models in order to determine the behaviour and level of accuracy of both models, and above all, its performance in a variety of conditions at a singular place such as the high mountain Observatory of Izaña. Both models represent the highest and the lowest levels related to the simplicity of atmosphere-structure and scattering-absorption processes in a ranking of spectral RTM. 


\section{Izaña observatory. Instrumentation and measurements}

The Izaña Observatory (IZO) is a Global Atmospheric Watch station located on the Canary Island of Tenerife at $28^{\circ} 18^{\prime} N, 16^{\circ} 29^{\prime} W$, $2.367 \mathrm{~m}$ above sea level. IZO is characterized by a clean air and pristine, but also by: a) frequent desert dust intrusions and b) a strong surface albedo because of the near permanent cloud layer below the altitude of the station known as "sea of clouds". The QASUME (Quality Assurance of Solar Ultraviolet Spectral Irradiance Measurements) intercomparison campaign took place at the Izaña Observatory during June 2005. In this campaign, seven UV spectroradiometers of different types were deployed [2]. In particular, in this work, we have utilized the measurements taken on 1st June 2005, with the Bentham DMT300 spectroradiometer. This instrument belongs to the University of Innsbruck, Institute of Medical Physics Austria (ATI).

\section{Radiative transfer models}

In this work, the LibRadtran and UVA-GOA models were used to simulate the UV spectral irradiance.

\subsection{LibRadtran model and input parameters}

The LibRadtran is a software library of radiative transfer routines and programs where the central part of the package is an executable program called Uvspec $[3,4]$. It is freely available at the web page: http://www.libradtran.org . The LibRadtran model is a multi-layer model with a complete treatment of the absorptionscattering processes offering a hundred of options and input parameters to handle all the structure that has an RTM. LibRadtran is divided into three main parts. The first part provides the optical properties needed as input for the radiative transfer equation (RTE) solver, including atmospheric properties, ozone profiles, surface pressure, cloud properties, temperature, etc. The second one solves the RTE based on different possible methods using the aforementioned optical properties, calculating radiances, irradiances and actinic fluxes. The last part of the code applies different elements to the output of the RTE solver such as convolution with a slit function, correction for Earth-Sun distance or multiplication with the extraterrestrial solar irradiance.

For example, in this paper the algorithm used for RTE solver is Disort2 (Discrete Ordinates Radiative Transfer 2.0), which is based on the multi-stream discrete ordinates algorithm developed by Stammes et al. [5]. The fundamental characteristics of this method are: one-dimensional geometry, plane parallel structure of the atmosphere, the use of the concept of layers to solve the RTE, and the possibility to consider both an inhomogeneous and non-isothermal atmosphere.

LibRadtran requires detailed information specified in input file with many different choices well described in $[3,4]$. The altitude profiles for ozone, pressure and temperature are taken from "in situ" measurements. In this work we use the monthly averages of ozone soundings series measured in Santa Cruz de Tenerife during the period between 1992 and 2007 [6].

The two most important parameters to introduce to the model in the UV range, are total column ozone and aerosol optical depth (indistinctly we use AOD or $\tau a)$. The measurement of total column ozone has been performed by the Brewer spectroradiometer. The daily average for $1^{\text {st }}$ June 2005 was $294 \pm 1$ Dobson Units (DU). The aerosol parameters used for the calculations are the AOD values at 340 $\mathrm{nm}$, the Ångström coefficient $\alpha$, the single scattering albedo $w_{o}$ and the asymmetry parameter, $g$. The latters are taken from the AERONET data of the Izaña station [7].

\subsection{UVA-GOA Model}

The UVA-GOA model was developed by Victoria Cachorro (Atmospheric Optics Group, Valladolid University GOA-UVA) during her PhD, with the aim to compare different simple solutions to RTE problems to develop a simple, fast, efficient and accurate model $[8,9]$. The solution to the RTE in a dispersive medium without absorption (optional) is usually separated into its direct and diffuse components. Thus the direct component is given by the Beer-Lambert-Bouguern equation, and the diffuse component by the 
solution of the RTE using the "Two-stream" or "Two-flux" method. However, direct component may or not be included as part of the RTE, and therefore we can obtain the flux (or transmittance) up and down, either from the diffuse component or from the global (direct plus diffuse) component. Besides, the model allows to consider a purely Rayleigh, purely aerosol atmosphere or a mixed atmosphere.

In a scattering Rayleigh atmosphere, the total transmittance due to global irradiance follows the formulation given by Sobolev [10] and applied by Vermote and Tanré [11] as:

$$
T_{R}=\left(\frac{2}{3}+\frac{1}{m}\right)+\left(\frac{2}{3}-\frac{1}{m}\right) \frac{\exp \left(-\tau_{R} m\right)}{\frac{4}{3}+\tau_{R}} \alpha,
$$

where $\tau_{R}$ is the Rayleigh optical depth and $\mathrm{m}$ is the optical mass. The transmittance due to aerosols scattering $T_{a}$ is given by the parameterized expression of Ambartsumian [10], which is based on the "Two stream" method:

$$
T_{a}(\mu)=\frac{\left(1-r^{2}\right) \exp \left(-k \tau_{a} m\right)}{1-r_{o}^{2} \exp \left(-k \tau_{a} m\right)},
$$

where $r_{o}$ and $k$ are given by:

$$
\begin{gathered}
r_{o}=\frac{k-1+w_{o}}{k+1+w_{o}}, \\
k=\sqrt{\left(1-w_{o}\right)\left(1-w_{o} g\right)}, \quad w_{o} \neq 1 .
\end{gathered}
$$

These two expressions are multiplied to obtain the total transmittance for an atmosphere considered as a mixture of aerosols and molecules, assuming no interaction between them. Equation (2) can also be taken to evaluate the transmittance of the global irradiance considering the interaction where the optical thickness is now the sum of Rayleigh and aerosol and where $g$ and $w_{o}$ should be also evaluated for this mixture. The optional absorption by atmospheric gases (ozone in this case) is accounted for by using a transmittance function which multiplies the scattering transmittance, so that no interaction is considered between scattering and absorption process. More details about the UVA-GOA model can be obtained in Cachorro et al. $[12,13]$. Since it is based on a onelayer model, the input parameters for this model are very simple: the SZA, pressure at the station, total column ozone, AOD at a given UV wavelength (340 $\mathrm{nm}$ may be used from AERONET), hence considered as constant, but alternatively the $\alpha-\beta$ Ångström coefficients may be used to consider the dependence on wavelength; finally, the surface albedo $\rho$ and the optical parameters $w_{o}$ and $g$.

\section{Results of the comparison}

Figures 1 and 2 present the comparison between the solar UV global irradiance spectra observed with the spectroradiometer Bentham and those simulated with the LibRadtran and UVA-GOA models for two different solar zenith angles (SZA), respectively $41.75^{\circ}$ and $6.66^{\circ}$, during the QASUME campaign at Izaña on 1st June 2005 [14]. In these plots, the UV spectral global irradiance simulated by the UVA-GOA model is slightly lower than those of the experimental measurements and LibRadtran model. In general the LibRadtran model gives a better agreement. The results of the UVA-GOA model show a strong dependence on the wavelengths in the UVB region. For the wavelengths below $320 \mathrm{~nm}$ the relative differences for UVA-GOA model range from $50 \%$ to $70 \%$, and decrease down to around $10 \%$ at $320 \mathrm{~nm}$. Beyond $320 \mathrm{~nm}$ these differences are less than $6 \%$.

The reason for this behaviour of UVA-GOA model is that the absorption effect is treated assuming no interaction with the scattering processes. As compared to UVA-GOA, the LibRadtran model gives lower differences in the whole spectral range, from $-8 \%$ to $+3 \%$. It overestimates the irradiances in the range of ozone absorption whereas it underestimates the radiation in the UVB range, with not relevant dependence on the SZA.

Table I shows the relative differences in integrated irradiances of both UVB (280-320 $\mathrm{nm}$ ) and UVA (320-400 nm) ranges between experimental measurements and each of the two models. In the UVB range, the differences are about $10-12 \%$ for low SZA increasing to $34 \%$ for SZA higher than $60^{\circ}$ for the UVA-GOA model. In the UVA range these differences are about $7 \%$ with no dependence on the SZA. As mentioned above, this dependence on SZA is also due to modeling of ozone absorption. The LibRadtran model gives differences around $1 \%$ increasing to 
$2 \%$ for high SZA, but they are similar for both spectral ranges. However, we can observe that UVA-GOA model presents a high stability in the UVA range when the LibRadtran model goes from overestimation at $320 \mathrm{~nm}$ to underestimation at $400 \mathrm{~nm}$ [14].

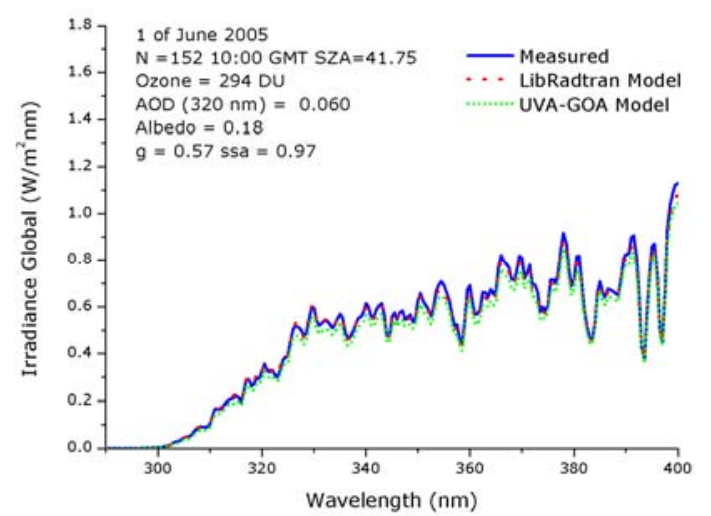

Fig. 1. Comparison between the solar UV global irradiance spectra observed with Bentham spectroradiometer at Izaña and simulated with LibRadtran and UVA-GOA models on $1^{\text {st }}$ June 2005 for $\mathrm{SZA}=41.75^{\circ}$.

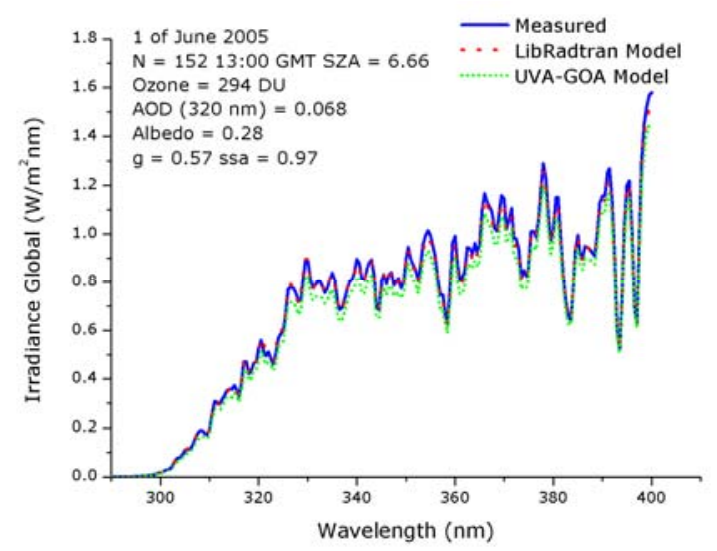

Fig. 2 . The same as Fig. 1 but $\mathrm{SZA}=6.66^{\circ}$ (solar noon).

Table I

Relative differences (in percent) between model calculations and measurements for UV global irradiance integrated over the UV-A and UV-B spectral ranges.

\begin{tabular}{||c|c|c|c|c|c||}
\hline \hline \multicolumn{2}{||c|}{} & \multicolumn{4}{|c|}{ UV-B [280-320 nm] } \\
\cline { 3 - 6 } \multicolumn{2}{||c|}{} & Meas./LibRadtran & \multicolumn{2}{c|}{ Meas./UVA-GOA } \\
\hline UTC & SZA $(\stackrel{\circ}{)})$ & Mean & Std. & Mean & Std. \\
\hline 10:00 & 41.75 & 0.863 & 3.779 & 15.050 & 5.847 \\
\hline $13: 00$ & 6.66 & -0.373 & 2.660 & 10.753 & 3.087 \\
\hline $18: 00$ & 66.40 & -1.938 & 5.843 & 33.937 & 16.344 \\
\hline & \multicolumn{4}{|c|}{ UV-A [320-400 nm] } \\
\cline { 3 - 6 } & & Meas./LibRadtran & \multicolumn{2}{|c|}{ Meas./UVA-GOA } \\
\hline UTC & SZA $\left(\varrho^{\circ}\right)$ & Mean & Std. & Mean & Std. \\
\hline 10:00 & 41.75 & 1.544 & 2.009 & 6.635 & 1.307 \\
\hline 13:00 & 6.66 & 0.826 & 1.713 & 6.588 & 1.280 \\
\hline 18:00 & 66.40 & 0.995 & 2.108 & 6.837 & 3.038 \\
\hline
\end{tabular}

\section{Conclusions}

The results of the intercomparison between LibRadtran, UVA-GOA models and experimental data, show differences varying with the spectral range and SZA. Although, and as expected, the best results are given by the LibRadtran model, the simplicity, fast and efficient capabilities of the UVA-GOA model makes it certainly more attractive for many applications. The differences between the latter and the LibRadtran can be principally explained by to three factors: 1 ) the monomodal layer of UVA-GOA versus the multilayer structure of the atmosphere introduced in the LibRadtran model, 2) the method used to solve the RTE and 3) the treatment of gaseous absortion making that UVA-GOA model overestimates the selective absorption of ozone. The results obtained with the UVA-GOA model in the UVA range are very satisfactory as the relative differences are within the instrumental uncertainty. Besides it should be noted that the UVA-GOA model had not been previously applied to high mountain environments.

\section{Acknowledgments}

This work was developed under the Specific Agreement of Collaboration between the University of Valladolid and the CIAI-AEMET "Establish methodologies and quality assurance systems for programs of photometry, radiometry, atmospheric ozone and aerosols within the atmospheric monitoring program of the WMO". Financial supports from the Spanish MICIIN (projects CGL2008-05939-C03-00/CLI and CGL200909740) and from the GR-220 Project of the "Junta de Castilla y León" are gratefully acknowledged. 